\title{
Tree rings reflect growth adjustments and enhanced synchrony among sites in Iberian stone pine (Pinus pinea L.) under climate change
}

\author{
Fabio Natalini ${ }^{1,3}$ - Alexandra Cristina Correia ${ }^{2}$. Javier Vázquez-Piqué ${ }^{1}$. \\ Reyes Alejano ${ }^{1}$
}

Received: 31 December 2014 / Accepted: 7 August 2015 / Published online: 25 September 2015

(C) INRA and Springer-Verlag France 2015

\begin{abstract}
- Key Message We used tree ring analysis to assess the response of Pinus pinea to climate change in South Iberia. Climate-growth relationships changed over time, with greater sensitivity in recent years due to increasing aridity. A common dendroclimatic signal among sites was found,
\end{abstract}

\section{Handling Editor: Lluis Coll}

Contribution of the co-authors Alexandra CORREIA: providing samples and tree-ring width measurements from the Pegões plot (Portugal), proofread the text; Javier VÁZQUEZ-PIQUÉ: designing the experiment, field work in Huelva, proofread the text; Reyes ALEJANO: supervising the work, field work in Huelva, proofread the text.

Electronic supplementary material The online version of this article (doi:10.1007/s13595-015-0521-6) contains supplementary material, which is available to authorized users.

Fabio Natalini

fabio.natalini@alu.uhu.es

Alexandra Cristina Correia

alexandrac@isa.utl.pt

Javier Vázquez-Piqué

jpique@uhu.es

Reyes Alejano

ralejan@uhu.es

1 Departamento de Ciencias Agroforestales, Escuela Técnica Superior de Ingeniería, Universidad de Huelva, Campus de La Rábida, 21819 Palos de la Frontera, Huelva, Spain

2 Centro de Estudos Florestais, Instituto Superior de Agronomia, Universidade de Lisboa, Tapada da Ajuda, 1349-017 Lisboa, Portugal

3 Análisis y Planificación del Medio Natural, Campus of Excellence CeiCambio, Departamento de Ciencias Agroforestales, Escuela Técnica Superior de Ingeniería, Universidad de Huelva, 21819 Palos de la Frontera, Huelva, Spain suggesting that climate change is the main responsible for the observed variation in tree growth.

- Context Understanding the response of Mediterranean forests to climate change is required to assess their vulnerability and to develop measures that may limit the impact of future climate change.

- Aims We analyzed the sensitivity of several populations of Pinus pinea (Stone pine) in Southern and Central Spain and Portugal to climate and identified some responses to climate change.

- Methods We constructed tree ring chronologies and studied the dendroclimatic signal over the last century.

- Results There were similarities in tree ring growth and response to climate among sites. Growth was enhanced after precipitation during the previous autumn and the current spring and was limited by water shortage. In recent decades, aridity increased in the study region and the sensitivity of tree ring growth to water availability increased at all study sites. We also observed an enhanced growth synchrony among chronologies as well as an increase in ring width variability during the last decades.

- Conclusion The radial growth of P. pinea indicated strong effects of climate change. The climatic signal in tree ring chronologies suggested a plastic growth response to climate of this species, although the enhanced growth synchrony and variability in recent years suggest the presence of conditions that are limiting for growth. This study provides the first assessment of the responses of Iberian populations of $P$. pinea to changes in climate.

Keywords Mediterranean pines · Tree-ring sensitivity · Climate-growth relationships $\cdot$ Regional growth synchrony 


\section{Introduction}

Climate change significantly affects the conservation, productivity, and management of forest ecosystems worldwide (see, e.g., Ciesla 1995). Climate models for the Mediterranean region forecast atmospheric warming, reduced rainfall, longer dry spells, and more frequent heat waves and heavy precipitation events (Kovats et al. 2014). These changes will alter plant phenology, decrease growth (especially in the southern provenances and at the edges of species ranges), reduce non-wood forest products, increase forest decline and die-back processes, change species distributions, and increase pests and fires (Lindner et al. 2010; Lindner and Calama 2013; Resco de Dios et al. 2007). Thus, studying the driving factors and the extent of changes in Mediterranean forests will provide important information on their ecological behavior and vulnerability and guide the implementation of management options that may improve their response to future climate change.

Dendrochronology and dendroecology provide valuable information on the response of forests to environmental factors (Fritts 1976; Schweingruber 1996; Cook and Kairiukstis 1990). Recent dendroecological studies in the Mediterranean basin demonstrated that tree ring data can be used as climate proxies in this region (e.g., Bogino and Bravo 2008; Campelo et al. 2009; Gea-Izquierdo et al. 2009, 2011; Vieira et al. 2010).

Stone pine (Pinus pinea L.) is native to southern Europe, occurs around the northern and eastern Mediterranean (Online Resource 1), and is present in more than 500,000 ha in the Iberian Peninsula (Montero González et al. 2004). In southern and central Iberia, stone pine stands are considered multifunctional forests because they provide wood and edible pine nuts that are highly valued in international markets (see Mutke et al. 2005). These trees also provide soil protection, sand dune stabilization, biodiversity refuge, space for public and recreational activities, and carbon sequestration (Montero González et al. 2004). Previous studies of $P$. pinea indicated a close relationship between radial growth and climatic factors and highlighted that tree ring formation in this species is sensitive to drought (Campelo et al. 2006; De Luis et al. 2009; Mazza et al. 2014; Novak et al. 2011; Raventós et al. 2001). Thus, tree ring analysis in this species can be potentially useful in climate change studies in the Mediterranean basin, which is considered particularly vulnerable to climate change (de Sherbinin 2014; Giorgi 2006). Nevertheless, no studies have yet thoroughly assessed climate change response in $P$. pinea populations, particularly those in Southern Iberia.

In this paper, we investigated the growth response of $P$. pinea populations to climate change in South and Central Spain and Portugal by examining the climatic signal in tree ring chronologies. Our working hypothesis were the following: (1) variations in climate entail a response in wood growth that will be reflected in temporal changes of the high-frequency response to climate; (2) if climate in a given region becomes more limiting for growth, different population from the same region will intensify their response to climate and will increase the shared variance in growth trends. To test the first hypothesis, we related the annual tree ring growth to the climate of the study areas and checked if climate-growth relationships varied over recent decades. To test the second hypothesis, we compared the highfrequency growth variability of the studied stands to detect similarities in the growth patterns and check whether these similarities were stable over time.

\section{Materials and methods}

\subsection{Study sites, samples, and tree ring analysis}

Samples were collected from six sites in the province of Huelva, in southwestern Spain (Campo común, El Portil, Moguer, Hinojos, Punta Umbría, and Valverde del Camino) and one site in Pegões, in central Portugal (Table 1, Online Resource 1). These woodlands are managed for production of pine nuts and timber and for the protection of coastal ecosystems. We also used three chronologies from the International Tree Ring Data Base (ITRDB, www.ncdc.noaa.gov/data-access/paleoclimatologydata/datasets/tree-ring) in the area of La Mancha (centraleastern Spain; Table 1, Online Resource 1): Dehesa del Peral, Pinar viejo and La Pasadilla (ITRDB codes: spai057, spai056 and spai059, respectively; contributors: Briongos and Del Cerro-Barja). The woodlands in this area are mainly managed for forest ecosystem conservation and timber production.

The climate in all areas is Mediterranean (Online Resource 2), but presents gradients in drought and precipitation regimes. Based on data from the meteorological stations of Huelva, Lisbon, Albacete, and Molina de Aragón (Online Resource 1), total annual precipitation and mean temperature are $520 \mathrm{~mm}$ and $18.2^{\circ} \mathrm{C}$ in Huelva, $730 \mathrm{~mm}$ and $16.9^{\circ} \mathrm{C}$ in Pegões, $362 \mathrm{~mm}$ and $13.8^{\circ} \mathrm{C}$ in Pinar Viejo and La Pasadilla, and $496 \mathrm{~mm}$ and $10.2^{\circ} \mathrm{C}$ in Dehesa del Peral. The annual distribution of rainfalls reaches a peak between November and February in Huelva and Pegões, while in the areas of La Mancha rainfall maximums normally occur in April-May and October. The dry period is larger in Huelva and Pegões (three months, from June to August), normally lasts for two months in Pinar Viejo and La Pasadilla (July-August) and one month in Dehesa del Peral (August) (Online Resource 2).

For the construction of the chronologies (Table 2), we used stem cross sections at breast height from previous harvests in Pegões (Correia et al. 2010). For Huelva, samples were extracted with an increment borer at breast height (two cores per tree), glued onto wooden mounts, and sanded along the transverse sections to make the rings visible. Tree ring widths were measured with a stereomicroscope and a LINTAB ${ }^{\mathrm{TM}}$ table (Rinntech $\left.{ }^{\circledR}\right)$ connected to a TSAP-Win ${ }^{\mathrm{TM}}$ tree ring analysis system $($ Rinntech () ). Ring width curves were plotted for visual inspection and cross-dated with determination of the 
Table 1 Geographic coordinates, elevations, and stand structural attributes of the study sites

\begin{tabular}{|c|c|c|c|c|c|c|c|}
\hline Geographic area & Site name & $\begin{array}{l}\text { Lat } \\
\left({ }^{\circ} \mathrm{N}\right)\end{array}$ & $\begin{array}{l}\text { Long } \\
\left({ }^{\circ} \mathrm{W}\right)\end{array}$ & $\begin{array}{l}\text { Elevation } \\
\text { (ma.s.l.) }\end{array}$ & $\begin{array}{l}\text { Mean diameter } \pm \text { st.dev. } \\
(\mathrm{cm})\end{array}$ & $\begin{array}{l}\text { Main height } \pm \text { st.dev. } \\
\text { (m) }\end{array}$ & $\begin{array}{l}\text { Stand } \\
\text { density } \\
\text { (trees/ha) }\end{array}$ \\
\hline \multirow{6}{*}{$\begin{array}{l}\text { Huelva } \\
\text { (south-west Spain) }\end{array}$} & Campo Común & 37.39 & 7.19 & 100 & $67 \pm 7$ & $22 \pm 1$ & 209 \\
\hline & El Portil & 37.21 & 7.04 & 20 & $22 \pm 8$ & $5 \pm 1$ & 264 \\
\hline & Moguer & 37.21 & 6.84 & 30 & $55 \pm 9$ & $17 \pm 3$ & 158 \\
\hline & Hinojos & 37.29 & 6.39 & 70 & $72 \pm 8$ & $20 \pm 1$ & 197 \\
\hline & Punta Umbría & 37.20 & 7.00 & 20 & $28 \pm 7$ & $7 \pm 1$ & 237 \\
\hline & $\begin{array}{c}\text { Valverde del } \\
\text { Camino }\end{array}$ & 37.53 & 6.78 & 260 & $62 \pm 6$ & $19 \pm 3$ & 300 \\
\hline Central Portugal & Pegões & 38.63 & 8.62 & 60 & $19 \pm 4$ & $15 \pm 3$ & 135 \\
\hline \multirow{3}{*}{$\begin{array}{l}\text { La Mancha } \\
\text { (central-eastern } \\
\text { Spain) }\end{array}$} & Dehesa del Peral ${ }^{\mathrm{a}}$ & 40.67 & 2.77 & 1057 & $34 \pm 6$ & $9 \pm 1$ & 450 \\
\hline & Pinar Viejo ${ }^{a}$ & 39.55 & 2.77 & 750 & $26 \pm 5$ & $8 \pm 1$ & 350 \\
\hline & La Pasadilla $^{\mathrm{a}}$ & 39.28 & 1.35 & 705 & $27 \pm 7$ & $9 \pm 1$ & 250 \\
\hline
\end{tabular}

${ }^{a}$ The chronologies in the area of La Mancha are from the International Tree Ring Data Base (ITRDB, see text for details)

coefficient of parallel variation (Gleichlaeufigkeit, Glk), $t$ value, and cross-date index (CDI). The Glk tests if two chronologies are simultaneously increasing or decreasing in each year-to-year interval and is calculated as the percentage of intervals showing matching growth variations (see Speer 2010, p. 108). The CDI was calculated in the TSAP-Win ${ }^{\mathrm{TM}}$ software as a combination of the $t$-value and the Glk (Rinn 2011). The cross-dating was verified using COFECHA (Grissino-Mayer 2001). For the stands from La Mancha, the ITRDB provided individual cross-dated ring-width series.

Each cross-dated ring-width series was standardized by applying a smoothing spline with a $50 \%$ frequency cutoff at
Table 2 Statistics of tree ring chronologies from Huelva (El Portil, Campo Común, Moguer, Hinojos, Punta Umbría and Valverde del Camino), Pegões and La Mancha (Pinar Viejo, Dehesa del Peral and La
Pasadilla). Time-spans include at least 5 cross-dated series with Expressed Population Signal $>0.85$ (see text for details)

\begin{tabular}{|c|c|c|c|c|c|c|c|c|c|c|}
\hline & El Portil & $\begin{array}{l}\text { Campo } \\
\text { Común }\end{array}$ & Moguer & Hinojos & $\begin{array}{l}\text { Punta } \\
\text { Umbría }\end{array}$ & $\begin{array}{l}\text { Valverde } \\
\text { del Camino }\end{array}$ & Pegões & $\begin{array}{l}\text { Pinar } \\
\text { Viejo }\end{array}$ & $\begin{array}{l}\text { Dehesa } \\
\text { del Peral }\end{array}$ & $\begin{array}{l}\text { La } \\
\text { Pasadilla }\end{array}$ \\
\hline $\begin{array}{l}\text { Time span } \\
\text { (years) }\end{array}$ & $\begin{array}{c}1952- \\
2011 \\
(60)\end{array}$ & $\begin{array}{c}1945- \\
2012 \\
(68)\end{array}$ & $\begin{array}{l}1946-2012 \\
(67)\end{array}$ & $\begin{array}{l}1866-2012 \\
(147)\end{array}$ & $\begin{array}{l}1902-2011 \\
(110)\end{array}$ & $\begin{array}{l}1881-2011 \\
\quad(131)\end{array}$ & $\begin{array}{c}1958- \\
2007 \\
(50)\end{array}$ & $\begin{array}{c}1906- \\
1999 \\
(94)\end{array}$ & $\begin{array}{l}1899-2001 \\
(103)\end{array}$ & $\begin{array}{c}1919- \\
2001 \\
(83)\end{array}$ \\
\hline $\begin{array}{l}\text { No. of trees } \\
\text { (no. of cores) }\end{array}$ & $20(40)$ & $17(34)$ & $17(34)$ & $19(38)$ & $17(34)$ & $20(40)$ & $24^{\mathrm{a}}$ & $13^{\mathrm{b}}$ & $21^{\mathrm{b}}$ & $26^{\mathrm{b}}$ \\
\hline $\begin{array}{l}\text { Mean width } \\
(\mathrm{mm})\end{array}$ & 2.4 & 3.7 & 2.7 & 2.1 & 1.4 & 1.8 & 3.2 & 1.4 & 2.0 & 2.5 \\
\hline $\begin{array}{l}\text { Median width } \\
\text { (mm) }\end{array}$ & 2 & 3 & 2.2 & 1.7 & 1.2 & 1.4 & 2.3 & 1.0 & 1.7 & 2.1 \\
\hline $\begin{array}{l}\text { Standard deviation } \\
\quad(\mathrm{mm})\end{array}$ & 1.5 & 2.3 & 1.9 & 1.5 & 0.8 & 1.3 & 2.5 & 1.2 & 1.1 & 1.6 \\
\hline Mean sensitivity & 0.28 & 0.20 & 0.32 & 0.37 & 0.28 & 0.23 & 0.26 & 0.36 & 0.24 & 0.30 \\
\hline \multicolumn{11}{|l|}{$\begin{array}{l}\text { First-order } \\
\quad \text { autocorrelation }\end{array}$} \\
\hline Raw series & 0.68 & 0.73 & 0.54 & 0.68 & 0.67 & 0.79 & 0.77 & 0.77 & 0.77 & 0.72 \\
\hline $\begin{array}{l}\text { After } \\
\text { standardization }\end{array}$ & 0.007 & 0.013 & 0.024 & 0.034 & 0.066 & 0.052 & 0.027 & 0.036 & 0.020 & 0.040 \\
\hline \multicolumn{11}{|l|}{ Mean correlation } \\
\hline $\begin{array}{l}\text { Series vs. master } \\
\text { chronology }\end{array}$ & 0.64 & 0.52 & 0.68 & 0.70 & 0.70 & 0.69 & 0.69 & 0.65 & 0.63 & 0.65 \\
\hline Among series & 0.37 & 0.36 & 0.55 & 0.48 & 0.40 & 0.49 & 0.77 & 0.54 & 0.45 & 0.41 \\
\hline
\end{tabular}

a 24 stem cross-sections were used for Pegões

${ }^{\mathrm{b}}$ Individual tree chronologies of the area of La Mancha (Pinar Viejo, Dehesa del Peral and La Pasadilla) were from the International Tree Ring Data Base (ITRDB, see text for details) 
32 years, the autocorrelation was removed, and growth indexes (Gi) were computed as the ratios between the observed ring widths and the values from the fitted spline (Cook et al. 1990). The 32-year wavelength produces a rather flexible spline which is a good filter to smooth the medium-frequency variability in the growth trends due to management and enhance the high-frequency climatic signal (see, e.g., Gea-Izquierdo et al. 2009, 2011; Helama et al. 2004). By averaging the Giseries with a biweight robust mean, a residual chronology was obtained for each stand (Cook et al. 1990). The standardization and computation of residual series were performed using the R software package (Venables and Smith 2015) with the dplR library (Bunn 2008). The residual chronologies eventually used in the subsequent dendroecological analyses only included years with at least five cross-dated series (GeaIzquierdo et al. 2011), and we checked that the included years had an Expressed Population Signal higher than 0.85, which is a measure of the confidence of the chronology in expressing the signal attributable to climate (Briffa and Jones 1990).

To identify the common dendroclimatic signal in the areas of Huelva and La Mancha, we performed principal component analyses (PCA). The use of PCA in dendroclimatic studies enables finding the common signal from a set of chronologies (e.g. Fritts 1990; D'Arrigo et al. 1999). For La Mancha, we computed the PCA of the correlation matrix of the residual series of Dehesa del Peral, Pinar Viejo, and La Pasadilla. The first principal component (PC) was used in subsequent analyses. The PCA was also performed for successive windows of 30 years to determine the stability of the common dendroclimatic signal.

The selected stands in Huelva are included in even-aged plots originated from plantations, with similar tree ages within each plot, but different ages between plots. Since tree response to climate can be age-dependent (e.g., Carrer and Urbinati 2004), we grouped the stands in Huelva into age clusters to increase the resolution of dendroclimatic signals (see Vieira et al. 2008). The age of the trees was firstly estimated by counting rings on each individual cross-dated chronology, from the ring closest to the pith up to the ring beneath the bark. Subsequently, the oldest and youngest trees were determined for each stand. On the basis of the observed tree age structure, the stands were eventually grouped into two age clusters: young ( $\leq 70$ years old) and old ( $\geq 100$ years old). The tree ages in the "young" cluster are equal or lower than the shortest rotation age for timber production in P. pinea in Spain, which is between 60 and 80 years, while tree ages in the "old" cluster are equal or higher than the optimal rotation age for timber and nut production, which ranges from 80 to 120 years (Montero González et al. 2004). The PCA of the correlation matrix of the series of each age cluster was then performed. The PC that contained the common dendroclimatic signal of each age cluster was used in subsequent analyses. As above, the PCA was performed for successive windows of 30 years.

\subsection{Climate and dendroecological analyses}

For climate change analysis over time, we used the series of self-calibrating Palmer Drought Severity Index (PDSI), which is based on the high-resolution surface climate data set CRU TS 2.1 of the Climate Research Unit of University of East Anglia, UK, and available in the KMNI Climate Explorer (http://climexp.knmi.nl; van der Schrier et al. 2006). Drought is the main growthlimiting factor in Mediterranean forests (see, e.g., Cherubini et al. 2003), so we considered this index to be a good descriptor of the impact of climate in our study areas.

For the analysis of the high-frequency response of radial growth to climate, we computed bootstrapped correlations and response functions using climatic covariates as independent variables and tree ring data as dependent variables. The climatic covariates were the monthly cumulative precipitation and the monthly averages of minimum and maximum temperatures computed from daily observations at the closest meteorological stations of the national weather services (see Online Resource 1), which were available in the KMNI Climate Explorer (Klein Tank et al. 2002). For the area of Huelva, the dependent variables used in correlation and response function analysis were the PCs of each tree age class and the climatic covariates were from the meteorological station of Huelva $\left(37.26^{\circ} \mathrm{N}, 6.9^{\circ} \mathrm{W} ; 19 \mathrm{~m}\right.$ a.s.l.; time span of precipitation and temperature records: 1920-2011). For Portugal, the analysis included the residual chronology of Pegões and the climatic data from the station of Lisbon $\left(38.72^{\circ} \mathrm{N}, 9.15^{\circ} \mathrm{W}\right.$; $77 \mathrm{~m}$ a.s.l.; time span of precipitation and temperature data: 1901-2012). For the area of La Mancha, in which the sites were farther apart and had larger climatic gradients, no single meteorological station was suitable; thus, correlation and response function analysis were performed separately for the residual chronologies of Dehesa del Peral, Pinar Viejo and La Pasadilla, using the closest available meteorological station for each site (see Online Resource 1). In particular, the station of Albacete $\left(38.95^{\circ} \mathrm{N}, 1.86^{\circ} \mathrm{W}\right.$; $704 \mathrm{~m}$ a.s.l.; time span of precipitation data: 1940-2010; time span of temperature data 1919-2010) was used for Pinar Viejo and La Pasadilla, and the station of Molina de Aragón $\left(40.84^{\circ} \mathrm{N}, 1.89^{\circ} \mathrm{W}\right.$; $1056 \mathrm{~m}$ a.s.1.; time span of precipitation data: 1950-2010; time span of temperature data: 1960-2010) was used for Dehesa del Peral. The bootstrapped correlations and response functions were computed with the bootRes library (Zang and Biondi 2012) in the R software package. Bootstrapped correlations were also performed for successive windows of 30 years to verify whether climate-growth relationships were stable over time. 
We used mean sensitivity (Ms, average of the relative differences in width from one ring to the next [Fritts 1976]) to determine the intensity of tree response to climate. Ms was calculated as:

$M s=\left(\frac{1}{n-1}\right) \times \sum_{t=1}^{t=n-1}\left|\frac{2 \times\left(x_{t+1}-x_{t}\right)}{x_{t+1}+x_{t}}\right|$

where $x$ is the growth index and $n$ is the number of annual rings in the tree-ring sequence. Thus, sensitivity ranges annually from 0 (in which adjacent rings have the same value) to 2 (in which a zero ["missing ring"] occurs next to a non-zero value) (Fritts 1976). As above, the Ms was computed for successive windows of 30 years to check if the intensity of response to climate varied over time.

For examination of the common dendroclimatic signal at a large scale, we compared the growth patterns by checking the cross-dating through the Glk coefficient and computing Pearson correlations between the study sites using the residual chronology from Pegões and the PCs from Huelva and La Mancha. Again, the correlations were computed for successive 30-year windows to test the stability of the common signal.

\section{Results}

\subsection{Chronologies}

In the area of Huelva, the youngest and oldest trees were 47 and 68 years old in El Portil, 53 and 70 in Campo Común, 52 and 69 in Moguer, 127 and 150 years old in Hinojos, 100 and 110 in Punta Umbría, and 120 and 139 in Valverde del Camino. Therefore, the chronologies from El Portil, Campo Común, and Moguer were included in the "young" cluster, while the chronologies from Hinojos, Punta Umbría, and Valverde del Camino were included in the "old" cluster. One PC, with eigenvalue $>1$ explained $70 \%$ of the variance of the chronologies included of the young cluster, and one PC, with eigenvalue $>1$, explained $72 \%$ of the variance of the chronologies in the old cluster. The variance accounted for by the first PC increased over recent decades for both old and young trees (Online Resource 3). The tree ages in Pegões ranged from 50 to 60 years. In the area of La Mancha, the youngest and oldest trees were 82 and 119 years old in Pinar Viejo, 65 and 113 in Dehesa del Peral, and 50 and 89 in La Pasadilla. One PC, with eigenvalue $>1$, explained $67 \%$ of the variance of the chronologies from La Mancha, and the amount of variance explained by this PC tended to increase over time (Online Resource 3).

\subsection{Dendroecological analyses}

Analysis of the PDSI series indicated increasing aridity during recent decades in Central Portugal, SW Spain, and CE Spain (Fig. 1). In particular, these regions had prolonged droughts, mainly in the 1970s, early 1980s, and mid-1990s. Furthermore, 30-year running inter-correlations between the PDSI series of the three areas showed an increase over time, with a mean value equal to 0.5 up to 1965 and a mean value of 0.75 in the subsequent decades, which suggests that the increase of aridity, with more frequent and severe droughts, is common at the large scale in our study region.

Radial growth of $P$. pinea trees in Huelva had a significant positive correlation with precipitation from the previous November to the current spring (up to May in old trees, March in young trees) (Fig. 2). Except for the young trees in Huelva (in which growth correlated with maximum temperature in the previous October), the relationship of growth and maximum temperature was not significant. However, there was a positive correlation of growth with minimum temperatures from December to February in old trees and from the previous October to the current January in young trees. In Pegões, radial growth correlated with precipitation from the previous October to February of the current year, had no significant relationship

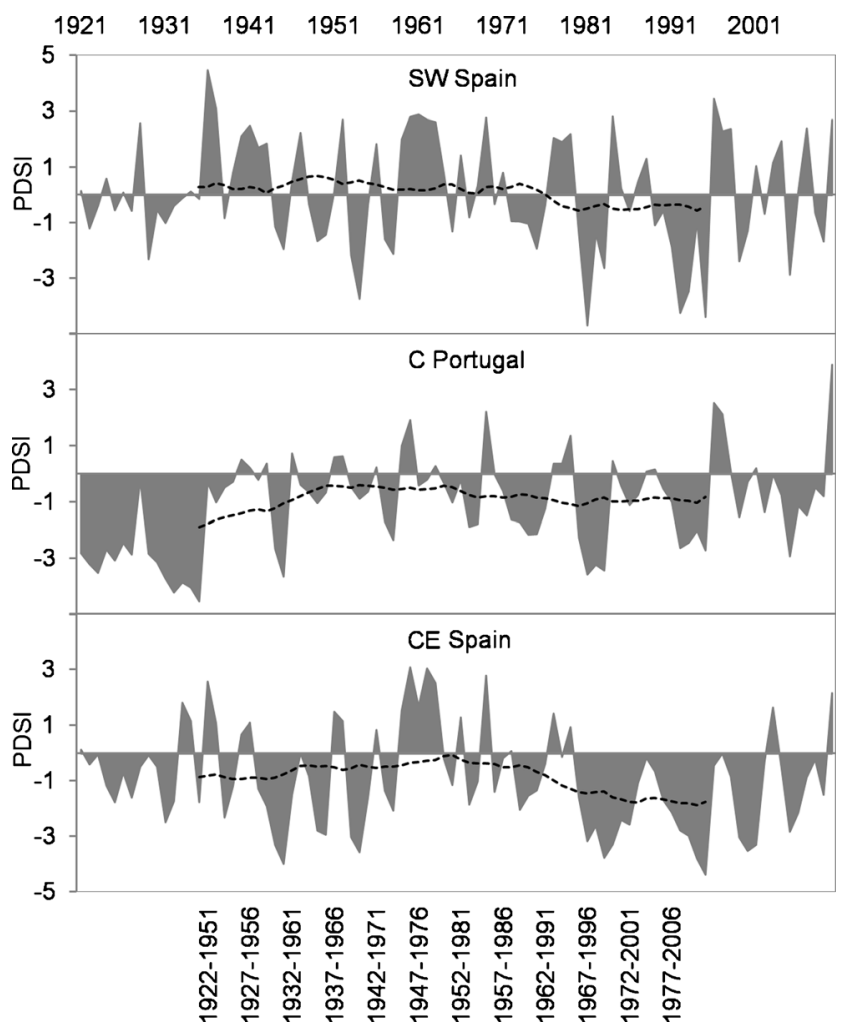

Fig. 1 Annual mean Palmer Drought Severity Index in south-west Spain, Central Portugal, and central-eastern Spain (the upper $x$-axis shows the years of the PDSI series). The dashed lines indicate 30-year moving averages centered in the mid-year of the window (the lower $x$-axis shows the 30-year windows of the moving averages) 
Fig. 2 Bootstrapped correlations (bars) and response functions (lines with dots) for monthly values of climatic covariates (precipitation, maximum temperature, minimum temperature) with the first principal component of old trees and young trees from Huelva and residual series from Pegões. Gray bars and black dots indicate statistically significant relationships $(p<0.05)$

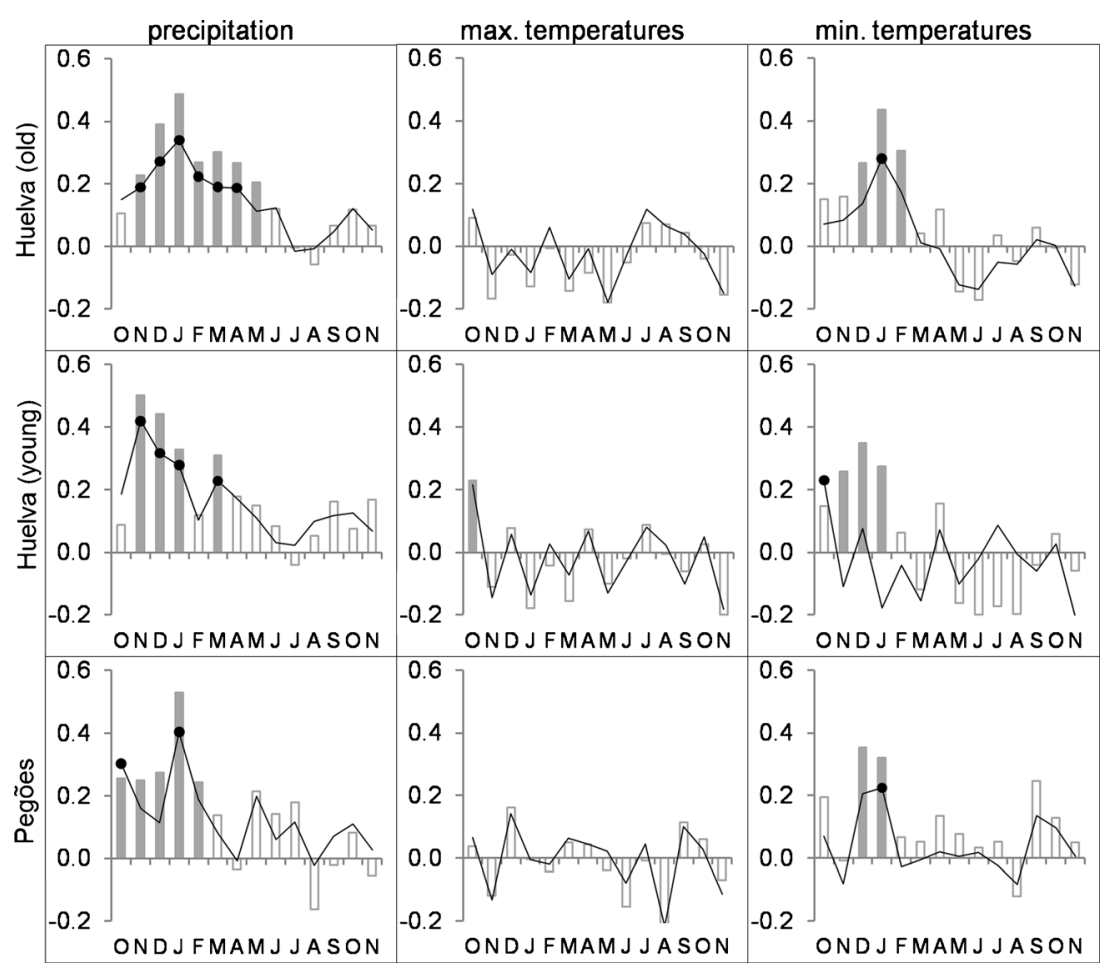

with maximum temperature, and had a positive correlation with minimum temperatures of December and January.

The chronologies in La Mancha indicated correlations of radial growth with precipitation in the previous November, winter, and the current May (Fig. 3). There was a negative correlation between maximum temperature and radial growth in La Pasadilla and Pinar Viejo in the previous October-November and the current May; in Dehesa del Peral, the correlation was negative in May and in summer. The relationship between minimum temperature and growth in La Pasadilla
Fig. 3 Bootstrapped correlations (bars) and response functions (lines with dots) between monthly values of climatic covariates (precipitation, maximum temperature, minimum temperature) and residual chronologies from La Mancha. Gray bars and black dots indicate statistically significant relationships $(p<0.05)$

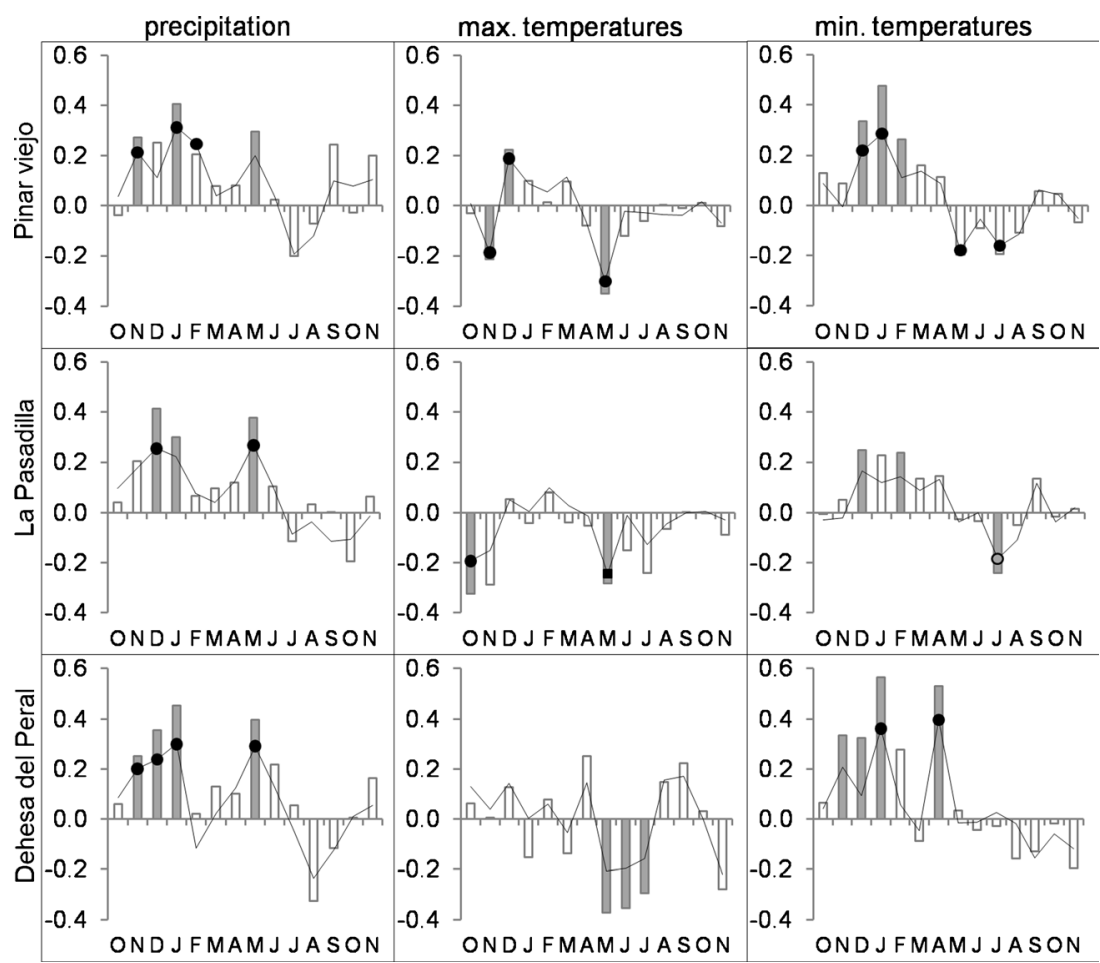


and Pinar Viejo was positive in winter and negative in May and July; in Dehesa del Peral, the correlation was positive in the previous November, winter, and current April.

The relationship of climate and radial growth changed over time in all study areas (Figs. 4 and 5). In particular, growth of old trees in Huelva had an increasing correlation with precipitation and minimum temperature of the previous December, and a declining correlation with spring rainfall. Growth of young trees in Huelva had negative correlations with May maximum temperature in the most recent decades, did not have significant correlations with March rainfalls between the 1960s and the 2000s, and became insensitive to rainfall in June since the 1960s, but was more correlated with temperature in February and precipitation of the previous October and the current September. The trees in Pegões had increasing dependence on rainfall of the previous November (there was also decreasing correlation with rainfalls in April, although not statistically significant). In Huelva, Pegões, and La Pasadilla, we found significantly negative correlations with temperature in June from the 1970s to the mid-1990s (Figs. 4 and 5), suggesting that radial growth was sensitive to high temperature during these years, characterized by extreme and prolonged droughts (Fig. 1). In La Mancha, analysis of all chronologies indicated increasing correlation with winter and current November precipitation, but decreasing correlation with rainfalls in March (and in June for Pinar Viejo), whereas the correlation with temperatures (Fig. 5) increased during winter and became negative in the current November.

The mean sensitivity of all tree ring series increased over the last decades (Online Resource 4), indicating an increasing intensity of the response to climate. Up to the 1960s, Ms in Huelva ranged from 0.1 to 0.3 , but increased in the subsequent decades and reached values between 0.3 and 0.5. In Pegões, Ms increased up to 0.3 from the 1970s and, in La Mancha, increased from 0.2 to 0.3 before the 1960 s to $0.3-0.4$ in subsequent decades.

The residual chronologies from Pegões and the PCs extracted from the chronologies in Huelva and La Mancha had good cross-dating and were significantly correlated (Table 3 ). Moreover, the correlations among these series increased over time, with a notable increase from the mid-1960s (Fig. 6). The mean correlations of the old trees in Huelva with Pegões, La Mancha, and the young trees in Huelva were 0.60, 0.34, and 0.68 , respectively, before the 1965 , whereas after this year were $0.63,0.58$, and 0.81 . The mean correlation of the young trees in Huelva with Pegões and La Mancha increased from 0.30 and 0.26 to 0.38 and 0.51 (the running correlation analysis between Pegões and La Mancha was not meaningful due to the short overlap).

\section{Discussion}

The P. pinea trees from the three study areas showed similarities in the high-frequency growth patterns and response to climate during the study period. These similarities indicate the presence of a common signal in the tree ring chronologies, suggesting that climatic factors control tree growth variability at a large scale irrespective of population distribution and local environmental conditions (Andreu et al. 2007; Čufar et al. 2014).

The correlations of radial growth with previous autumn and winter rainfall reflect the importance of soil recharge for improving water availability and subsequent growth in the spring. These results agree with previous studies of $P$. pinea in Portugal (Campelo et al. 2006) and Spain (Raventós et al. 2001) and with studies of other Mediterranean species (e.g., Campelo et al. 2009; Corcuera et al. 2004; David et al. 2007).
Fig. 4 Thirty-year runningwindow bootstrapped correlations between monthly values of precipitation and temperature (months of previous year are in capital letters) with the first PC of old trees and young trees from Huelva and residual series from Pegões. Horizontal solid and dotted lines indicate thresholds for statistically critical values ( $\alpha=$ 0.01 and $\alpha=0.05$, respectively)

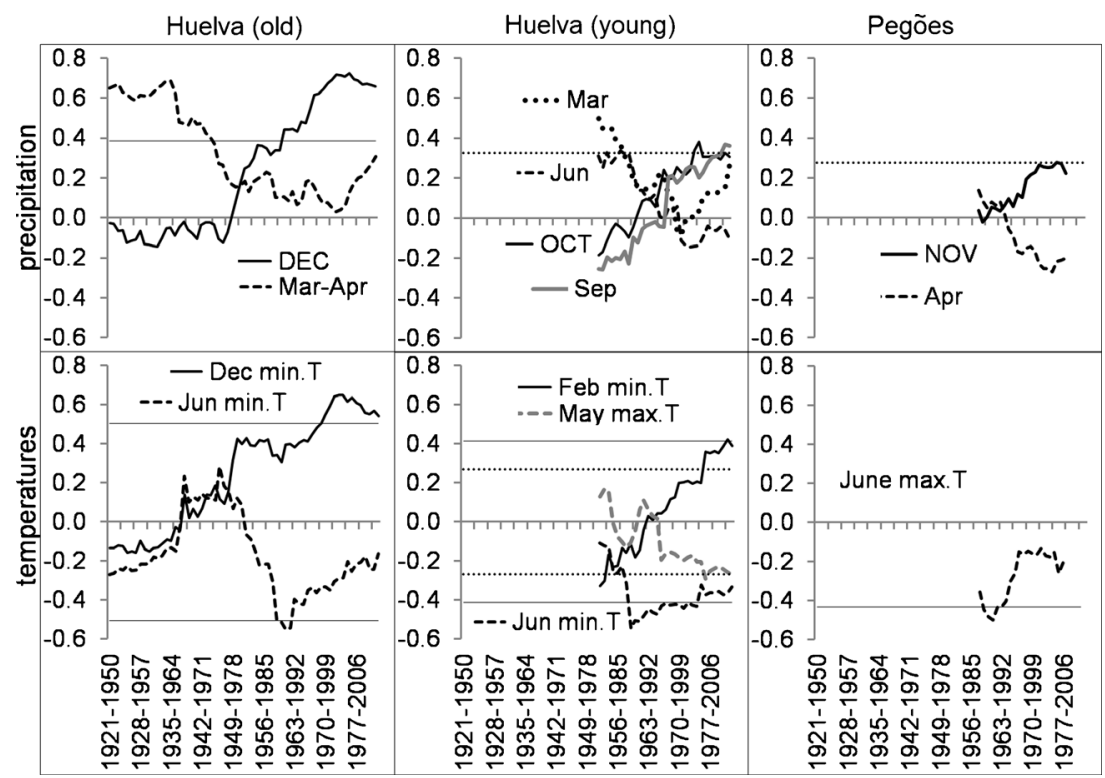


Fig. 5 Thirty-year runningwindow bootstrapped correlations between monthly values of precipitation and temperature (months of previous year are in capital letters) and chronologies from La Mancha. Horizontal solid and dotted lines indicate thresholds for statistically critical values $(\alpha=0.01$ and $\alpha=0.05$, respectively). There were no significant results after the correlation analysis between Dehesa del Peral and temperatures due to the short time span of the temperature records in the meteorological station of Molina de Aragón

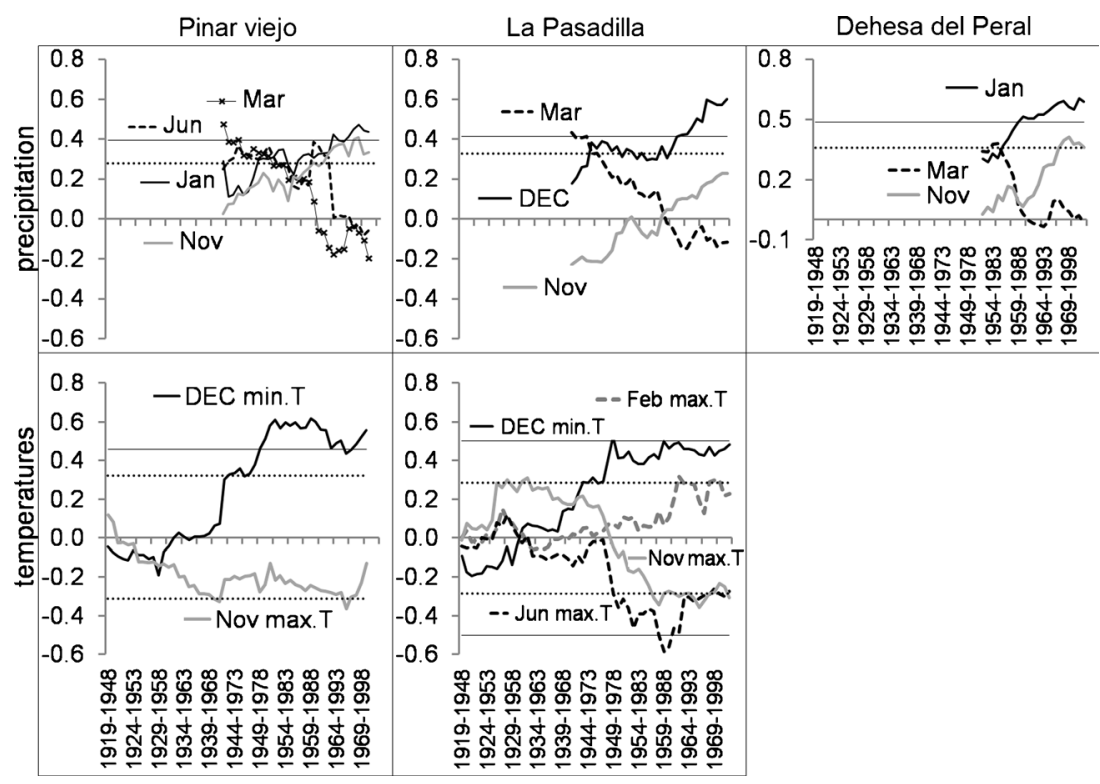

Moreover, for evergreen trees, the positive response to rainfall and mild temperature in winter suggests the dependency of ring formation on the photosynthesis and carbohydrates produced during this period (Baldocchi et al. 2010). Mild temperatures during the winter can also alter phenological patterns, inducing an early dormancy interruption and consequently the formation of wider rings (Begum et al. 2010; Oribe and Kubo 1997).

The dendroclimatic signal that we recorded also reflected the influence of local climatic factors. The stands in La Mancha had higher responses to precipitation in May; this can be partly explained by the rainfall maximum occurring in May in this area (Online Resource 2), which provides an important water supply for ring formation. We found no relationship between summer climate and radial growth in the drier sites, Huelva and Pegões (Fig. 2). This can be expected for trees growing under these conditions (Campelo et al. 2009; Gea-Izquierdo et al. 2011), in which scarce and irregular summer rainfall is insufficient to alleviate water stress due to the high temperature, and there may even be a contraction of the radial growth. In contrast, trees in La Mancha were sensitive

Table 3 Glk and Pearson correlation coefficients $(r)$ calculated from pair-wise comparisons between the residual chronologies from Pegões and the PCs from Huelva and La Mancha. Significance of Pearson correlation coefficients is indicated in brackets

\begin{tabular}{llll}
\hline & Huelva (young) & La Mancha & Pegões \\
\hline Huelva (old) & Glk:76\% & Glk: $67 \%$ & Glk: $75 \%$ \\
& $r: 0.76(\mathrm{p}<0.01)$ & $r: 0.54(\mathrm{p}<0.01)$ & $r: 0.64(\mathrm{p}<0.01)$ \\
Huelva (young) & & $G l k: 62 \%$ & Glk: $67 \%$ \\
& & $r: 0.36(\mathrm{p}<0.05)$ & $r: 0.41(\mathrm{p}<0.01)$ \\
La Mancha & & & Glk: $75 \%$ \\
& & & $r: 0.55(\mathrm{p}<0.01)$ \\
\hline
\end{tabular}

to summer temperatures although did not correlate to precipitation in this season. This suggests that in La Mancha, even though summer rainfall is scarce, the growing season is extended throughout summer, so that the radial growth can be affected by high temperatures during this season (Gea-Izquierdo et al. 2009).

Age-mediated response to climate has been observed in different species, and climates and the interpretation of forest dynamics can be improved if the age effect is accounted for (Carrer and Urbinati 2004). In Huelva, the growth of young

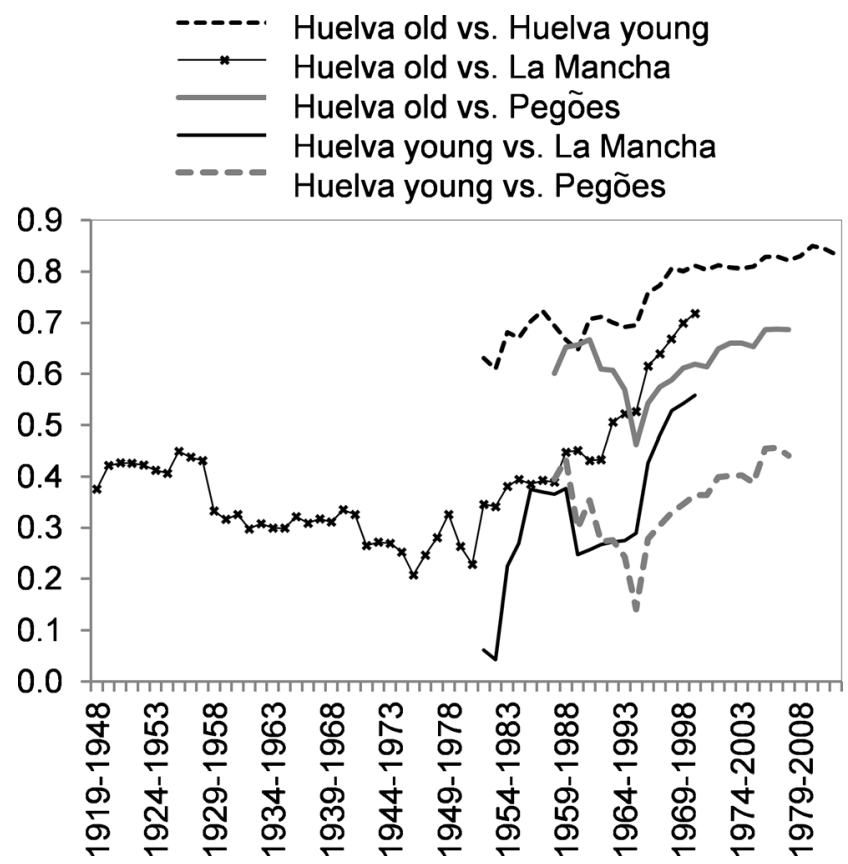

Fig. 6 Pearson's correlations for 30-year moving windows calculated as pair-wise comparisons between the residual chronologies from Pegões and the PCs from Huelva and La Mancha. The $x$-axis shows the 30year intervals 
trees correlated with temperature and was more sensitive to rainfall in the previous autumn than old trees (Fig. 2). This may indicate that, under the same climatic conditions, young trees respond more rapidly to climate than older trees, and xylogenesis in young trees is higher in the earlier phases of the growing season (Rossi et al. 2008). Vieira et al. (2008) reported similar observations for P. pinaster in the Mediterranean climate of central Portugal.

Previous studies reported that spring precipitation increased radial growth in Mediterranean pines (e.g., Vieira et al. 2010; Campelo et al. 2006; De Luis et al. 2009, 2013; Piraino et al. 2013; Novak et al. 2013) and other Mediterranean trees (e.g., Campelo et al. 2009; Gea-Izquierdo et al. 2011). Although we found similar results for the old trees in Huelva, showing a positive correlation with rainfall up to May (Fig. 2), the young trees in Huelva and in Pegões (see Figs. 2 and 4) were less sensitive to spring precipitation. The time span covered by the tree ring sequences of the young trees (El Portil, Campo Común and Moguer in Huelva and Pegões, see Table 2) largely overlapped with the downward slope of the PDSI curves (Fig. 1). This means that the young trees grew under more xeric conditions, which possibly limited the cambial activity in the warmer months and consequently led to a weak chronology signal related to spring rainfall. This also suggests that the different dendroclimatic signals observed in trees of different ages depends not only on endogenous growth factors (i.e., physiological changes related to aging, see e.g., Rossi et al. 2008; Szeicz and Macdonald 1994) but also on the climatic conditions in which the trees were established and developed.

The observed changes in the relationships between climate and growth reflect the non-stationary nature of the growth responses of trees to climate (Carrer and Urbinati 2006). Other Iberian Mediterranean tree stands exhibited changes in highfrequency responses to climate suggesting a reaction to warming and increased water stress (Gea-Izquierdo et al. 2009; Martín-Benito et al. 2010). Wood anatomy and physiological studies indicate that tree species present some degree of plasticity to changing environmental conditions, i.e., the ability of a genotype to adjust the phenotype as a result of the physiological responses to environmental variability (see Fonti et al. 2010). For example, alterations in plant phenology, including seasonal xylem growth patterns, have been observed with atmospheric warming (Peñuelas et al. 2002; Rossi et al. 2011; Deslauriers et al. 2008). We may speculate that the plastic variations in climate-growth relationships observed in our study can be the result of a phenological adjustment of the cambial activity in relation to the distribution of water availability over the year (de Luis et al. 2011; Camarero et al. 2010). This could explain that, under more xeric conditions observed in recent decades, $P$. pinea ring growth became less sensitive to climatic conditions in the spring when higher temperatures increased the water stress and enhanced its dependence on water availability in the previous autumn-winter and current autumn when climate is milder. We made similar observations in our dendroecological studies for Quercus ilex in Huelva (data not published). Although in the young trees we observed that the chronology signal related to spring climate was weak (in Huelva) or absent (in Pegões), improved relationships with autumn/winter climate were found. Therefore, an alteration of climate-growth relationships was observed in all sites with a reduction of the growth sensitivity to climate in the warmer months and an enhanced dependence of growth on the milder months (also see Fig. 7 in GeaIzquierdo et al. 2009; and Fig. 7 in Martín-Benito et al. 2010). This suggests that climate variability in the region induce similar responses in the cambial activity of trees from different populations.

The similarity in the high-frequency growth variability among sites can be interpreted as a common response to the regional climate (Andreu et al. 2007; Macias et al. 2006; Tardif et al. 2003). Trees with Ms values greater than 0.4 are considered extremely sensitive to climate, while trees with Ms values lower than 0.2 are less climate-sensitive (Speer 2010, p. 107). In our sites, the Ms values increased in recent years (Online Resource 4), indicating that trees were exposed to harsh environmental conditions that controlled growth to a wider extent. In agreement with our findings, previous research in Iberian forests also reported high year-to-year variability of growth at dry sites (Campelo et al. 2006; Nabais et al. 2014) and increases in Ms over time (Andreu et al. 2007; Martín-Benito et al. 2010; Tardif et al. 2003; GeaIzquierdo et al. 2009). Furthermore, the good cross-dating and correlation among sites in our study region support the presence of a significant dendroclimatic signal at the large scale. In particular, the increased similarity in growth patterns (Online Resource 3 and Fig. 6) indicates increasing growth synchrony. This suggests that, despite the differences in the dendroclimatic signal related to local environmental conditions and tree age structure, the climate of the region becomes increasingly important as a factor driving the variability of ecosystem growth. The increase of aridity over the second half of the twentieth century matching the increase of Ms and growth synchrony (Fig. 1, Online Resource 4 and Fig. 6), together with the clear dependence of growth on water availability (Figs. 2, 3, 4 and 5), suggests that the observed changes in the growth patterns were linked to the higher frequency, severity and duration of droughts (Andreu et al. 2007).

\section{Conclusions}

In this study, we have found a robust dendroclimatic signal in newly established $P$. pinea tree ring chronologies in Southwestern Spain and Central Portugal and archived chronologies from Central-Eastern Spain. We provide a valuable 
assessment of the sensitivity of Iberian sites of $P$. pinea to changing growing conditions. The growth of studied trees was sensitive to high temperatures and water shortage, as the most limiting factors in Mediterranean forests. Our findings suggest that cambial activity adjusted to the increased water stress. In recent decades, the inter-annual variability of growth increased, indicating an intensified response to climate, and there was enhancement of growth synchrony among forests, reflecting that climatic conditions became more limiting for growth. We also observed that climate change induced similar responses in the cambial activity over wide areas, including forests with different site characteristics and ages. Further research is needed to assess the degree to which climate change impacts can be mediated by the stand age structure and local site conditions. These issues can improve the knowledge regarding species vulnerability to climate change and should be taken into account for forest growth modeling and adaptive management.

Acknowledgments FN thanks D. Martín Pérez and students from the Escuela Politécnica Superior, Universidad de Huelva, for helping with sample collection and processing. The authors acknowledge the Environmental Council in Huelva and the staff of the Department for Environment of the Government of Andalusia for their support in locating the study sites.

Funding This study was supported by the Spanish Ministry of Economy and Competitiveness, the European Union (FEDER funds), the Spanish National Agriculture Research Institute (project ref:RTA2013-00011575 C02-02), the Department of Innovation, Science and Business of the Regional Government of Andalusia, Spain (project ref: P07RNM02688), and the International Campus of Excellence for Environment, Biodiversity and Global Change (CeiCambio)

\section{References}

Andreu L, Gutiérrez E, Macías M, Ribas M, Bosch O, Camarero JJ (2007) Climate increases regional tree-growth variability in Iberian pine forests. Glob Chang Biol 13:804-815

Baldocchi DD, Ma SY, Rambal S, Misson L, Ourcival JM, Limousin JM, Pereira J, Papale D (2010) On the differential advantages of evergreenness and deciduousness in Mediterranean oak woodlands: a flux perspective. Ecol Appl 20:1583-1597

Begum S, Nakaba S, Oribe Y, Kubo T, Funada R (2010) Cambial sensitivity to rising temperatures by natural condition and artificial heating from late winter to early spring in the evergreen conifer Cryptomeria japonica. Trees-Struct Funct 24:43-52

Bogino SM, Bravo F (2008) Growth response of Pinus pinaster Ait. to climatic variables in central Spanish forests. Ann For Sci 65:506506

Briffa K, Jones PD (1990) Basic chronology statistics and assessment. In: Cook ER, Kairiukstis LA (eds) Methods of dendrochronology: applications in the environmental sciences. Kluwer Academic Publishers, Dordrecht, pp 137-152

Bunn AG (2008) A dendrochronology program library in R (dplR). Dendrochronologia 26:115-124

Camarero JJ, Olano JM, Parras A (2010) Plastic bimodal xylogenesis in conifers from continental Mediterranean climates. New Phytol 185:471-480
Campelo F, Nabais C, Freitas H, Gutiérrez E (2006) Climatic significance of tree ring width and intra-annual density fluctuations in Pinus pinea from a dry Mediterranean area in Portugal. Ann For Sci 64: 229-238

Campelo F, Nabais C, García-González I, Cherubini P, Gutiérrez E, Freitas H (2009) Dendrochronology of Quercus ilex L. and its potential use for climate reconstruction in the Mediterranean region. Can J For Res 39:2486-2493

Carrer M, Urbinati C (2004) Age-dependent tree-ring growth responses to climate in Larix decidua and Pinus cembra. Ecology 85:730-740

Carrer M, Urbinati C (2006) Long-term change in the sensitivity of treering growth to climate forcing in Larix decidua. New Phytol 170: $861-872$

Cherubini P, Gartner BL, Tognetti R, Braker OU, Schoch W, Innes JL (2003) Identification, measurement and interpretation of tree rings in woody species from Mediterranean climates. Biol Rev Camb Philos Soc 78:119-148

Ciesla WM (1995) Climate change, forests and forest management: an overview. FAO, Rome

Cook ER, Kairiukstis LA (1990) Methods of dendrochronology: applications in the environmental sciences. Kluwer Academic Publishers, Boston

Cook ER, Briffa KR, Shiyatov S, Mazepa V (1990) Tree-ring standardization and growth-trend estimation. In: Cook ER, Kairiukstis LA (eds) Methods of dendrochronology: applications in the environmental sciences. Kluwer Academic Publishers, Boston, pp 104-123

Corcuera L, Camarero JJ, Gil-Pelegrin E (2004) Effects of a severe drought on growth and wood anatomical properties of Quercus faginea. IAWA J 25:185-204

Correia AC, Tomé M, Pacheco CA, Faias S, Dias AC, Freire J, Carvalho PO, Pereira JS (2010) Biomass allometry and carbon factors for a Mediterranean pine (Pinuspinea L.) in Portugal. Forest Syst 19:418433

Čufar K, Grabner M, Morgós A, Martínez del Castillo E, Merela M, de Luis M (2014) Common climatic signals affecting oak tree-ring growth in SE Central Europe. Trees-Struct Funct 28:1267-1277

D'Arrigo R, Wiles G, Jacoby G, Villalba R (1999) North Pacific sea surface temperatures: past variations inferred from tree rings. Geophys Res Lett 26:2757-2760

David TS, Henriques MO, Kurz-Besson C, Nunes J, Valente F, Vaz M, Pereira JS, Siegwolf R, Chaves MM, Gazarini LC, David JS (2007) Water-use strategies in two co-occurring Mediterranean evergreen oaks: surviving the summer drought. Tree Physiol 27:793-803

De Luis M, Novak K, Čufar K (2009) Raventós J (2009) Size mediated climate-growth relationships in Pinus halepensis and Pinus pinea. Trees-Struct Funct 23:1065-1073

De Luis M, Novak K, Raventós J, Gričar J, Prislan P, Čufar K (2011) Cambial activity, wood formation and sapling survival of Pinus halepensis exposed to different irrigation regimes. Forest Ecol Manag 262:1630-1638

De Luis M, Čufar K, Di Filippo A, Novak K, Papadopoulos A et al (2013) Plasticity in Dendroclimatic Response across the Distribution Range of Aleppo Pine (Pinus halepensis). PLoS ONE 8, e83550. doi:10. 1371/journal.pone.0083550

De Sherbinin A (2014) Climate change hotspots mapping: what have we learned? Clim Chang 123:23-37

Deslauriers A, Rossi S, Anfodillo T, Saracino A (2008) Cambial phenology, wood formation and temperature thresholds in two contrasting years at high altitude in southern Italy. Tree Physiol 28:863-871

Fonti P, von Arx G, García-González I, Eilmann B, Sass-Klaassen U, Gärtner H, Eckstein D (2010) Studying global change through investigation of the plastic responses of xylem anatomy in tree rings. New Phytol 185:42-53

Fritts HC (1976) Tree rings and climate. Academic Press, London

Fritts HC (1990) Statistical reconstruction of spatial variations in climate using 65 chronologies from semiarid sites. In: Cook ER, Kairiukstis 
LA (eds) Methods of dendrochronology: applications in the environmental sciences. Kluwer Academic Publishers, Dordrecht, pp 193-211

Gea-Izquierdo G, Martín-Benito D, Cherubini P, Cañellas I (2009) Climate growth variability in Quercus ilex L West Iberian open woodlands of different stand density. Ann Forest Sci 66:802

Gea-Izquierdo G, Cherubini P, Cañellas I (2011) Tree-rings reflect the impact of climate change along a temperature gradient in Spain over the last 100 years. Forest Ecol Manag 262:1807-1816

Giorgi F (2006) Climate change hot-spots. Geophys Res Lett 33

Grissino-Mayer HD (2001) Evaluating crossdating accuracy: a manual and tutorial for the computer program COFECHA. Tree-Ring Bull 57:205-221

Helama S, Lindholm M, Timonen M, Eronen M (2004) Detection of climate signal in dendrochronological data analysis: a comparison of tree-ring standardization methods. Theor Appl Climatol 79:239 254

Klein Tank AMG et al (2002) Daily dataset of 20th century surface air temperature and precipitation series for the European Climate Assessment. Int J Climatol 22:1441-1453

Kovats RS, Valentini R, Bouwer LM, Georgopoulou E, Jacob D, Martin E, Rounsevell M, Soussana JF (2014) Europe. In: Barros VR, Field CB, Dokken DJ, Mastrandrea MD, Mach KJ, Bilir TE, Chatterjee ME, Ebi KL, Estrada YO, Genova RC, Girma G, Kissel ES, Levy AN, MacCracken S, Mastrandrea PR, White LL (eds) Climate Change 2014: Impacts, Adaptation, and Vulnerability. Part B: Regional Aspects. Contribution of Working Group II to the Fifth Assessment Report of the Intergovernmental Panel on Climate Change. Cambridge University Press, Cambridge, pp 1267-1326

Lindner M, Calama R (2013) Climate Change and the Need for Adaptation in Mediterranean Forests. In: Lucas-Borja ME (ed) Forest management of Mediterranean forests under the new context of climate change: building alternatives for the coming future. Nova Science Publishers, New York, pp 13-30

Lindner M, Maroschek M, Netherer S, Kremer A, Barbati A, GarciaGonzalo J, Seidl R, Delzon S, Corona P, Kolstro M, Lexer MJ, Marchetti M (2010) Climate change impacts, adaptive capacity, and vulnerability of European forest ecosystems. Forest Ecol Manag 259:698-709

Macias M, Andreu L, Bosch O, Camarero JJ, Gutiérrez E (2006) Increasing aridity is enhancing Silver Fir Abies Alba Mill. Water stress in its South-Western distribution limit. Clim Chang 79:289 313

Martín-Benito D, Del Río M, Cañellas I (2010) Black pine (Pinus nigra Arn.) growth divergence along a latitudinal gradient in Western Mediterranean mountains. Ann For Sci 67:401

Mazza G, Cutini A, Manetti MC (2014) Site-specific growth responses to climate drivers of Pinus pinea $\mathrm{L}$. tree rings in Italian coastal stands. Ann For Sci 71:927-936

Montero González G, Candela Plaza JA, Rodríguez Navarro A (eds) (2004) El pino piñonero en Andalucía: ecología distribución y selvicultura. Dirección General de Gestión del Medio Natural, Consejería de Medio Ambiente, Junta de Andalucía, Sevilla

Mutke S, Gordo J, Gil L (2005) Variability of Mediterranean Stone pine cone production: yield loss as response to climate change. Agr Forest Meteorol 132:263-272

Nabais C, Campelo F, Vieira J, Cherubini P (2014) Climatic signals of tree-ring width and intra-annual density fluctuations in Pinus pinaster and Pinus pinea along a latitudinal gradient in Portugal. Forestry. doi:10.1093/forestry/cpu021

Novak K, De Luis M, Čufar K, Raventós J (2011) Frequency and variability of missing tree rings along the stems of Pinus halepensis and Pinus pinea from a semiarid site in SE Spain. J Arid Environ 75: 494-498

Novak K, de Luís M, Raventós J, Čufar K (2013) Climatic signals in treering widths and wood structure of Pinus halepensis in contrasted environmental conditions. Trees-Struct Funct 27:927-936

Oribe Y, Kubo T (1997) Effect of heat on cambial reactivation during winter dormancy in evergreen and deciduous conifers. Tree Physiol 17:81-87

Peñuelas J, Filella I, Comas P (2002) Changed plant and animal life cycles from 1952 to 2000 in the Mediterranean region. Glob Chang Biol 8:531-544

Piraino S, Camiz S, Di Filippo A, Piovesan G, Spada F (2013) A dendrochronological analysis of Pinus pinea L. on the Italian midTyrrhenian coast. Geochronometria 40:77-89

Raventós J, De Luís M, Gras MJ, Čufar K, González-Hidalgo JC, Bonet A, Sánchez JR (2001) Growth of Pinus pinea and Pinus halepensis as affected by dryness, marine spray and land use changes in a Mediterranean semiarid ecosystem. Dendrochronologia 19:211-220

Resco de Dios V, Fischer C, Colinas C (2007) Climate change effects on Mediterranean forests and preventive measures. New Forest 33:29 40

Rinn F (2011) TSAP-Win ${ }^{\mathrm{TM}}$ : time series analysis and presentation for dendrochronology and related applications. Rinntech ${ }^{\circledR}$, Heidelberg

Rossi S, Deslauriers A, Anfodillo T, Carrer M (2008) Age-dependent xylogenesis in timberline conifers. New Phytol 177:199-208

Rossi S, Morin H, Deslauriers A, PLOURDE PY (2011) Predicting xylem phenology in black spruce under climate warming. Glob Chang Biol 17:614-625

Schweingruber FH (1996) Tree rings and environment. Dendroecology. Paul Haupt Publishers, Vienna

Speer J (2010) Fundamentals of tree-ring research. The University of Arizona Press, Tucson

Szeicz JM, Macdonald GM (1994) Age-dependent tree-ring growth responses of subarctic white spruce to climate. Can J For Res 24:120 132

Tardif J, Camarero JJ, Ribas M, Gutiérrez E (2003) Spatiotemporal variability in tree growth in the Central Pyrenees: climatic and site influences. Ecol Monogr 73:241-257

van der Schrier G, Briffa KR, Jones PD, Osborn TJ (2006) Summer moisture variability across Europe. J Clim 19:2818-2834

Venables WN, Smith DM (ed.) (2015) An introduction to R. R Core Team, http://cran.r-project.org/doc/manuals/r-release/R-intro.pdf Accessed 7 July 2015

Vieira J, Campelo F, Nabais C (2008) Age-dependent responses of treering growth and intra-annual density fluctuations of Pinus pinaster to Mediterranean climate. Trees-Struct Funct 23:257-265

Vieira J, Campelo F, Nabais C (2010) Intra-annual density fluctuations of Pinus pinaster are a record of climatic changes in the western Mediterranean region. Can J For Res 40:1567-1575

Zang C, Biondi F (2012) Dendroclimatic calibration in R: the bootRes package for response and correlation function analysis. Dendrochronologia. Dendrochronologia 31:68-74 